\title{
D.E. Wittkower:
}

\section{The Vital Non-Action of Occupation, Offline and Online}

\begin{abstract}
:
Using an Arendtian framework, I argue that we can understand distinctive and effective elements of the \#OWS movements as forms of non-action related to prior strategies of non-violence, the propaganda of the deed, and coalitions of affinity rather than identity. This understanding allows us to see that, while the use of social media in the movement does not provide the same affordances for building and maintaining power as physical occupation, and while online community clearly cannot substitute for physical community in many relevant and consequential ways, Facebook does nonetheless provide a platform well suited to maintaining power through these distinctive forms of non-action.
\end{abstract}

\section{Agenda:}

Power and Violence.

Power and the City

The Virtualized Occupation

\section{Author:}

Asst. Prof. Dr. D.E. Wittkower

- Old Dominion University, Department of Philosophy, 5115 Hampton Boulevard, Norfolk, VA, 23529, USA

- 魚 + 01 - 757 - 683 3864, $ه$ dwittkow@odu.edu

- Relevant publications:

- Facebook and Philosophy. D.E. Wittkower (Ed.). Chicago: Open Court 2010, 285 p.

- „Friend is a Verb," APA Newsletter on Philosophy and Computers, forthcoming Fall 2012. 
The Occupy movement is subject to frequent criticism regarding its forms of non-action, both from those who support the movement and from more hostile critics. These forms of non-action are signature characteristics of the movement: 1 . Occupation of and encampment in public spaces; 2 . Seemingly non-political activities such as drum circles, yoga, and meditation; 3. Relative disinterest in electoral politics; and 4. The refusal to have a defined agenda, platform, or list of demands or desired outcomes. The use of social media and the dismantling of encampments seems to have moved the movement even further from action into non-action and trivial practices of "raising awareness" about an unfocused array of concerns. Using Hannah Arendt's understanding of power, I argue that these elements of \#OWS are a productive absence, and represent a novel and effective structure of forming and maintaining political power online and offline.

\section{Power and Violence}

In The Human Condition, Hannah Arendt defines power as "what keeps the public realm, the potential space of appearance between acting and speaking men, in existence," and comments that it is always "a power potential and not an unchangeable, measurable, and reliable entity like force or strength." ${ }^{1}$ This allows her to give an account of non-violent action through passive resistance that articulates the inverse relation between force and power:

"Popular revolt against materially strong rulers ... may engender an almost irresistible power even if it foregoes the use of violence in the face of materially vastly superior forces. To call this "passive resistance" is certainly an ironic idea; it is one of the most active and efficient ways of action ever devised, because it cannot be countered by fighting, where there may be defeat or victory, but only by mass slaughter in which even the victor is defeated, cheated of his prize, since nobody can rule over dead men."

In the contemporary American context, thankfully, protesters do not face mass slaughter, but the same analysis applies, although not because the population in question is dead after the application of violence. Since the beginning of the occupy movement, protesters have seen abusive but non-lethal applications of state violence, including the use of rubber bullets, pepper spray, and simple excessive use of force in arrests. These unexpected eruptions of violence demonstrate the power of the \#OWS movement through the vehemence of state reaction against it, and this demonstration is all the more effective through occupiers' general refusal to descend to fighting, where the state may become victorious. Here, rule is undermined through the fact of unilateral violence. As Arendt says in On Violence, "Violence appears where power is in jeopardy, but left to its own course it ends in power's disappearance. This implies that it is not correct to think of the opposite of violence as nonviolence; to speak of non-violent power is actually redundant." ${ }^{3}$

Non-violent passive resistance, of course, began long before \#OWS, and these dynamics of power and violence are not new. What is new and distinctive in the occupation movement is that non-violence has been extended into non-action. To be sure, occupations march, shout slogans in the street, pamphlet, engage in civil disobedience, and so forth-but occupations also occupy, which we might define incompletely as the public demonstration of the existence of a public, and an assertion of rights of assembly and speech. The refusal to have a singular and exclusive platform, list of demands, or vertical hierarchy allows the non-action of occupation to demonstrate that state violence against protesters is not an action taken against a particular element in society or a particular political agenda, but rather the allergy of the state to the power of the people as such. By refusing to have any particular, clear, unifying claim or outcome, occupation is able to make its distinctive case all the more forcefully: that the idea of power to the people, outside of the structures of monied interests, is itself a threat to contemporary American pseudo-democracy. By eliciting violence through the performance of the minimal prerequisites of democratic society, in the absence of any other essential content, occupation

1 Arendt, Hannah: The Human Condition. 200.

2 Arendt, Hannah: The Human Condition. 200-201.

3 Arendt, Hannah: On Violence. 56. 
demonstrates that, to adapt Irigaray, ours is a democracy which is not one; defined in terms foreign to its own nature, in which the people are "only a more or less obliging prop."4

\section{Power and the City}

Hannah Arendt also claims that

"The only indispensable material factor in the generation of power is the living together of people. Only where we live so close together that the potentialities of action are always present can power remain with them. ... What keeps people together after the fleeting moment of action has passed (what we today call "organization") and what, at the same time, they keep alive through remaining together is power. "5

In the fracturing of society under late capitalism, the potentialities of action have become increasingly abstract. In American culture, New York City is emblematic of this fracturing, which takes place along lines of class, race, sexuality, and language-emblematic because of the great diversity of the city, the perceived "coldness" and disconnection of its residents, and the great but absent possibility of solidarity and power in such a huge concentration of human lives lived in proximity to one another. The Zuccotti Park occupation, a performance of the political meaning of cities through voluntary and cooperative cohabitation, gained symbolic force through its presence in this city, and in particular through its location in the coldest and most inhumanly bureaucratic part of New York: the financial district; Wall Street. Where the actions taken are not explicitly political in nature-as in the processes of cohabitation; providing food, shelter, and medical care; or singing, drum circles, yoga, and meditation-they are political by implication, for they create and bring vitality to the community which lies dormant, and whose power lies sleeping.

Occupation encampments are pop-up cities that demonstrate in microcosmic actuality the power that lies dormant and all-but-forgotten within the permanent macrocosmic cities that are their hosts. The danger represented by occupations takes place through the mere demonstration of potential power, where power is itself a mere potential for action. Political action in occupation is two orders removed; doubly potential: occupation as a form of cohabitation that makes action possible creates power in the absence of action, the implicit and explicit claim of which is that such power, such potential for action, is potentially there in the host cities as well. Were the host cities able to organize into a people holding power, broad and transformative social action would be possible, and the mere possibility of this kind of action is sufficiently dangerous to motivate severe and violent raids and crackdowns, massively disproportionate to and placed in sharp contrast by the inactivity of occupation. Occupations provide a proof of concept of solidarity under American late capitalism; this is their intent, and power structures that range against social solidarity have taken pre-emptive action in a way and to a degree that reflects an at least unconscious awareness of this intent. The efficacy of the non-action of occupation is that solidarity can be expressed in the absence of action and message; what can be expressed in silence cannot itself be silenced-or, as those in the movement have phrased it, "You cannot arrest an idea."

Mikhail Bakunin wrote that "[a]ll of us must now embark on stormy revolutionary seas, and from this very moment we must spread our principles, not with words but with deeds, for this is the most popular, the most potent, and the most irresistible form of propaganda."6 This call for a propaganda of the deed has been taken up in a number of forms, certainly not all of them violent, but the most shocking and infamous form of adoption of the idea was in the wave of murders and assassinations committed by anarchists from the late nineteenth to early twentieth centuries. The intent of these attacks was to lay bare that the powerlessness of those subject to the rule of royals and government did not flow from anything other than the failure to say "no." Where anarchists once took to shooting people wielding force in order to show that they are still subject to the power of people, occupation as a propaganda of the non-deed takes place at a level more fundamental: not by showing

4 Irigaray, Luce: This Sex Which is Not One. 25.

5 Arendt, Hannah: The Human Condition. 201.

6 Bakunin, Mikhail: Bakunin on Anarchism. 195-6. 
that we can rise against our masters, but by showing that direct action is possible; that the people as such can still have politics.

\section{The Virtualized Occupation}

These dynamics are in an interesting tension with the occupation movement's use of ICTs. Various occupations have used ICTs in different ways, but Facebook seems often to play a prominent role, especially in those occupations whose encampments have been destroyed. Facebook becomes a virtual space where occupation may continue in a different form-where occupiers, even at a distance, can continue to "live together" in a sense relevant to Arendt's-but it is far from clear that many and the most important political potentials and meanings are preserved as occupation shifts online. Can we have a city of bits (Mitchell 1995) that preserves Arendt's understanding of the political meaning of the city, or is our online cohabitation irredeemably refracted and diffused?

In discussions of friendship online, several scholars (e.g. Condella 2010, McFall 2012), have taken the position that social media may be able to maintain friendships but are insufficient to support online-only genuine friendships. Perhaps the case may be similar here: that social media cannot serve as a location from which power may arise, but can serve as a location where power can be maintained; that online cohabitation can serve the internal but not the external functions of occupation.

It is certainly and obviously the case that a "virtualized" occupation-one whose encampment has been destroyed and which binds occupiers' lives together primarily through online rather than offline interaction and sharing-is no longer subject to crackdowns and raids in the same way as a physical occupation. ${ }^{7}$ This, along with a lack of presence in public locations, means that the occupation is no longer as apparent in the media or in the accidental everyday encounters of city life. With this, many of the external functions of occupation disappear: the virtual occupation does not draw out the public violence of the state through public non-action, and does not present a propaganda of the non-deed through its presence. The pull-orientation of online information, compared to the push of information through physical proximity, results in an opt-in default for awareness.

But while these external functions are not well served in a virtual occupation, internal functions do seem to be served. Through consistent information-sharing of both political and quotidian information, a feeling of lived presence of others may be maintained, opening up possibilities of action. The friend feed can serve as a space where occupiers can find themselves among a community of others who assert the need for intervention and the efficacy of direct action.

In virtualization, occupations have in a sense gone underground: it is not that occupations are "hiding" online, but that the power of occupiers in community with one another now enters public view only at the moment when that power is transformed into action, and at those moments of action occupiers do not appear in the non-action that characterizes and identifies the movement. Where virtual occupations organize to support strikes, the action appears as an action of labor, not of the occupation movement. Virtual occupations often take up issues of housing-homelessness and foreclosures-but these actions do not appear to the public or to the media as occupations. In an example local to me, when virtual occupations, including Occupy Virginia, Occupy Norfolk, Occupy Richmond, Occupy Virginia Beach, and Occupy Charlottesville, organized to protest the state's mandatory ultrasound anti-choice bill, ${ }^{8}$ this was reported as an action taken by feminists and pro-choice

7 I take care to emphasize "in the same way" in this claim. As Seda Gürses rightly pointed out to me (personal communication, Sept. 19, 2012), we do not know to what extent virtualized occupations and occupiers in virtual spaces have been subject to electronic and informational analogues of crackdowns and raids. This lack of public knowledge, of course, is what leads to the failure of virtual analogues to have the same political meaning and impact as physical raids on physical occupations, but electronic and virtual state actions against occupiers may certainly be significant and troubling, and the issue is an important one, calling for future investigation.

8 Virginia House Bill no. 462 required women seeking an abortion to undergo a medically-unnecessary ultrasound imaging of the fetus, and imposed a 24-hour waiting period following the imaging, with the exceptions of women living at least 100 miles from the facility where the procedure is to be performed. Given that the ultrasound imaging serves no medical purpose, and given that the legislation 
activists. The virtualized networks of power of the occupations continue to open possibilities for direct action, but as the inactive power has been virtualized, the occupation itself seems to have disappeared. In reality, though, it is only that their power, when it is realized in action, appears under other flags.

In what, then, does this virtualized non-action consist, such that it is able to maintain the power of occupiers even in the absence of physical occupation? Certainly it includes sharing political images and arguments, and engaging in discussion and debate, but it also includes sharing recipes, discussing family and personal issues, sharing pictures, and generally living lives more or less open to one another. As I have argued elsewhere (Wittkower 2012) social media postings and interactions are not merely informational in nature, but interpersonal and relational as well, and the posting of material can constitute asynchronous shared experiences at a distance.

These forms of sharing, perhaps particularly those which do not themselves have political content, recreate in at least a shadow or placeholder form the experience of cohabitation that binds people together in bonds of understanding and social trust. As made clear in Putnam's Bowling Alone among other places, simple activities taken together produce social frameworks for and psychological dispositions to principles action, and studies (e.g. Boase et al. 2006, Ogilvy Public Relations Worldwide and Georgetown University's Center for Social Impact Communication 2011) have found that online connection can support the same bonds of trust and support for action. The seeming triviality of practices of Facebook sharing, in this way, in not to the detriment of the power of virtual communities of occupiers, but instead supports power by providing an experience of community that includes elements of life falling outside of organizing for action. It is this non-action, togetherness in these times between events, that allows power to persist rather than to be dissipated when an action is completed.

Another obvious threat of dissipation of power is presented by the multiplicity of political concerns and causes of action espoused and promoted in politics as conducted on Facebook. How, we might ask, is a group to be effective when its members wish to mobilize variously in favor of tax reform; against inequality; in favor of environmental concerns; against corporate welfare; in favor of urban homesteading; against war, in favor of debt forgiveness; against Citizens United; in favor of universal healthcare; against GMOs; in favor of direct democracy; against racism; in favor of women's, gay, and minority rights; and so forth? This concern is further compounded by the prevalence of views considered by the majority of Americans to be conspiracy theories, such as the claim that " $9 / 11$ was an inside job" perpetrated by or along with the United States government or its elected officials, and by anti-Zionist views which border on anti-Semitism and sometimes explicitly reference conspiratorial views of international banking conspiracies which have previously served as racist canards.

While extreme views and divisive conspiracy theories do present serious threats to maintaining power in the movement, for the most part the diversity of causes and concerns have aided in maintaining power through one of the same dynamics of non-action discussed above: by refusing to allow the movement to be "about" a single thing, power is not channelled into any particular action, outcome, or concern, allowing the core "empty" position of occupation-power to the people-to be maintained and upheld all the more strongly through this diversity of concerns. The dynamic is one discussed by Haraway in her "Cyborg Manifesto." She notes how in the American civil rights movement, the experiences of black women tended to be excluded as a distraction from issues of race, while at the same time black women's experiences tended to be excluded from the feminist movement as a similar distraction from women's issues, leaving black women in a neither-nor position. Haraway contrasts this with the political language of "women of color": an affinity identification which does not require women of color to have similar backgrounds, physical characteristics, or experiences in order to be part of the same group of common support and action. The kaleidoscopic array of causes propounded by virtual occupations supports maintenance of power through an inclusive affinity structure: by refusing to sideline concerns

seems to have been based on model legislation produced by a model bill written by Americans United for Life, an anti-abortion law and policy organization, the bill was widely regarded as a paternalistic attempt to discourage women from excersizing their right to obtain an abortion. Of particular concern was the fact that, since most women seeking an abortion are early enough in pregnancy to require the ultrasound to be performed transvaginally, the bill required an unwanted, medically-unnecessary, invasive, and potentially-painful procedure that was compared to "state-required rape" by its opponents. In response to the protests, the bill was rewritten to allow women to opt-out of transvaginal ultrasound in favor of an external, transabdominal ultrasound, and was signed into law in this form. 
as "distractions from action," nobody's experiences are excluded and the movement is able to retain its openness and identity as a cause of common causes rather than a cause exclusive of other causes.

Through this Arendtian analysis of power, we see that the occupation movement has used various forms of non-action-ranging from the refusal to have an agenda to the seemingly non-political actions of living in community with others-in order to maintain power rather than to allow it suffer dissipation between moments of direct action. This analysis allows us to see what is lost through the virtualization, but also to see how the affordances of Facebook are able to support power in the movement through forms of online non-action in community. While we are right to question claims about the inherent pro-democratic and revolutionary nature of social media, and to take care not to overemphasize the role that Facebook has played in the occupation movement, we can see that Facebook is remarkably well-suited to maintaining inactive power of the kind distinctive of occupation.

\section{References}

Arendt, Hannah: The Human Condition. Chicago: University of Chicago Press 1958. : On Violence. New York, Harcourt, Brace \& World 1969.

Bakunin, Mikhail: Bakunin on Anarchism. Sam Dolgoff ed. Montréal: Black Rose Books 2002.

Boase, Jeffrey; Horrigan, John B.; Wellman, Barry; Rainie, Lee: The Strength of Internet Ties. Online, Pew Internet \& American Life Project 2006. http://www.pewinternet.org/ /media//Files/Reports/2006/PIP_Internet_ties.pdf.pdf

Condella, Craig: "Why Can't We Be Virtual Friends?," in Facebook and Philosophy, D.E. Wittkower ed. Chicago: Open Court 2010.

Haraway, Donna: "A Cyborg Manifesto," in Simians, Cyborgs, and Women. New York, Routledge 1990.

Irigaray, Luce: This Sex Which is Not One. New York, Cornell University Press 1985.

McFall, Michael: "Real character-friends: Aristotelian friendship, living together, and technology," Ethics and Information Technology (2012) 14:221-230.

Mitchell, William: City of Bits. Cambridge, MIT Press 1995.

Ogilvy Public Relations Worldwide; Georgetown University's Center for Social Impact Communication: Dynamics of Cause Engagement. 2011. http://csic.georgetown.edu/research/215767.htm/

Putnam, Robert: Bowling Alone. New York, Simon \& Schuster 2000.

Wittkower, D.E.: "Friend is a Verb," APA Newsletter on Philosophy and Computers (2012) 12.1:22-26. 